\title{
Intrapartum Ultrasonography for Prediction of Vaginal Delivery: Review
}

\author{
Vajinal Doğumu Öngörmede \\ İntrapartum Ultrasonografinin Yeri
}

\section{Ayla ESER, ${ }^{a}$ \\ Aydın KÖŞÜŞ, ${ }^{a}$ \\ Nermin KÖşÜŞa}

aDepartment of Obstetrics and Gynecology, Turgut Özal University Faculty of Medicine, Ankara

Geliş Tarihi/Received: 11.07.2014

Kabul Tarihi/Accepted: 30.12.2014

Yazıșma Adresi/Correspondence:

Ayla ESER

Turgut Ozal University Faculty of Medicine, Department of Obstetrics and Gynecology, Ankara,

TÜRKIYE/TURKEY

aylaacar76@yahoo.com.tr

\begin{abstract}
Intrapartum ultrasound imaging is gaining popularity, with increased application due to its relative ease of use and direct on-site accessibility. Though its use was initially restricted to esoteric indications and routinely applied antepartum, sonography is now increasingly being used for more mundane intrapartum indications, for example illustration of the precise fetal head position, assessment of fetal head engagement and estimation of the fetal weight. Advance evaluation of the complex physiology of childbirth is now possible with intrapartum ultrasonography, including Doppler flow velocimetry. It is not, however, in current use for the purposes of pure clinical management, i.e. development of labor or the lack thereof. The increased rate of cesarean delivery is a worldwide problem. Medico-legal problems, however, can arise from difficult vaginal deliveries. Internationally, finding ways to reduce cesarean delivery rates is a clinical priority. This includes development of new techniques for encouraging normal vaginal delivery. Appropriate use of intrapartum sonography could contribute to reduction of cesarean delivery rates and help to protect patients and doctors from possible complications of difficult vaginal delivery. Detection of advancing cervical dilatation and descent of the fetal head, however, are two important aspects currently beyond the clinical scope of intrapartum ultrasound imaging. Determination of the descent of the fetal head will be the ultimate challenge of clinical applicability of intrapartum ultrasound imaging. The hope is that imaging ultrasound will ultimately permit us to assess these two vital clinical parameters, which have up until now proven indefinable.
\end{abstract}

Key Words: Parturition; ultrasonography; labor, obstetric

ÖZET İntrapartum ultrasonografik görüntülemenin, uygulama kolaylı̆̆ı, direkt erişilebilirliği ve artan uygulama alanları ile popülerliği artmaktadır. Sonografinin ilk uygulama alanları yalnızca özel bilgisi olanlar tarafından anlaşılabilen endikasyonlar ve antepartum uygulamalar ile sınırlı olsa da, son zamanlarda olağan intrapartum endikasyonlar için de kullanılmaktadır. Bu uygulamalar, fetal baş pozisyonunun gösterimi, fetal baş angajmanının değerlendirmesi ve fetal ağırlık tahminini içermektedir. Günümüzde intrapartum ultrasonografi ile doğumun karmaşık fizyolojisinin (doppler akım çalışmalarını içeren) ileri değerlendirmesi mümkün olmaktadır. Klinik yönetimin tamamında kullanılmamakla birlikte doğum seyrini (veya olamayacağını) tahminde yardımcıdır. Artan sezaryenle doğum oranları dünya genelinde bir problemdir. Bir başka problem ise zor vajinal doğumdan kaynaklanan mediko-legal olayların artıyor olmasıdır. Tüm dünya ülkeleri sezaryen doğum oranlarını azaltmanın yollarını aramaktadır. Normal vajinal doğumu teşvik edecek yeni yöntemler geliştirmenin arayışı içindedirler. Intrapartum sonografi tekniği, sezaryen doğum oranını azaltmanın yanısıra hastaları ve doktorları zor vajinal doğumda oluşabilecek komplikasyonlardan korumaya yardımcı olabilir. Ancak servikal dilasyon seyri ve fetal baş inişi gibi iki önemli konu hala intrapartum ultrasonografi kapsamı dışında kalmaktadır. Umuluyor ki ileride ultrasonografik görüntüleme, bu iki hayati klinik parametreyi değerlendirmeyi de sağlayacaktır.

Anahtar Kelimeler: Normal doğum; ultrasonografi; doğum, obstetrik

Turkiye Klinikleri J Gynecol Obst 2016;26(3):146-51 doi: 10.5336/gynobstet.2014-41381

Copyright ( 2016 by Türkiye Klinikleri 


\section{T} ntrapartum ultrasound has recently been explored extensively to study the progress of labor and predict the possibility of a vaginal delivery. ${ }^{1}$ Further understanding of the complex physiology of childbirth is possible due to intrapartum ultrasonography. It has been shown to provide objective information on the dynamics of different stages of labor. The prognosis for operative vaginal delivery can also be assessed by intrapartum ultrasonography. ${ }^{2}$

Avoiding complicated vaginal delivery is the primary focal point of the current obstetric practice. Digital transvaginal examination, which is highly dependent on the clinician's ability and is still regarded 'gold standard' for obstetric practice, has several limitations. ${ }^{3}$ A relatively new potential purpose for ultrasound in tracking the progress of labor is therefore developing and the process of gathering knowledge is underway to demonstrate its effectiveness and applicability. ${ }^{4}$ By merit of its safety and non-invasive nature, given appropriate circumstances intrapartum ultrasound examination is applicable for most, if not all, indications currently considered in the antepartum arena.

Assessment of fetal head station with respect to the narrowest part of the maternal bony pelvis is of essential importance to allow vaginal delivery to take place. Recent surveys have indicated that ultrasound imaging might allow dynamic and objective quantification of the degree of fetal head descent in the birth canal. ${ }^{3}$ Various sonographic modalities have been employed in the intrapartum determination of the fetal head engagement. ${ }^{5}$ Success in nonoperative vaginal birth mainly depends on the fetal descent and thus it is a central element in the clinical evaluation of progress of labor. Malrotation of the fetal head is largely due to the lack of descent, causing relative cephalopelvic disproportion. Clinical assessment of fetal descent is normally carried out by biased and inaccurate digital vaginal assessment regarding the maternal ischial spines. ${ }^{6}$ The presence of molding of the fetal head often makes this evaluation more imprecise. In this respect, fetal descent assessment by intrapartum sonographic is a promising prospect as it may po- tentially present a better objective evaluation in comparison with digital vaginal assessment. ${ }^{6}$

Ultrasound examination offers valuable information before the beginning of labor, such as placental localization, presence of a neck-cord or Vasa previa, fetal presentation, weight, wellbeing, depiction of prematurity and prolonged pregnancy information. The collateral applicability of ultrasound during labor has also been the subject of many studies, for example, assessment before epidural catheter placement; ${ }^{7}$ intrapartum maternal symphyseal separation by transverse suprapubic ultrasound examination; ${ }^{8}$ intrapartum fetal behavior and prediction of adverse perinatal outcome based on amniotic fluid amount or biophysical profile; ${ }^{9}$ depiction of the molding and caput succedaneum during, but also before labor; ${ }^{10} \mathrm{ma}-$ ternal and fetal intrapartum pulsed Doppler blood flow assessment; ${ }^{11}$ intrapartum myometrial thickness changes, ultrasound use in the third stage of labor, or the assessment of the post void residual volume in laboring and postpartum women with or without epidural analgesia. ${ }^{7}$

\section{INTRAPARTUM ULTRASOUND IN LABOR}

Several pieces of evidence suggest that the clinical evaluation during labor is not always accurate, with potential significant implications in decision making and prognosis of delivery mode. Various studies have suggested that with the unorthodox configuration of the maternal pelvis and comparatively large dimensions of the fetal head at term, not all diameters of the latter necessarily pass through all diameters of the maternal pelvis. So, vaginal delivery requires the necessary adjustment or adaptation of various parts of the fetal head to different segments of the pelvis. Such alterations in place include the engagement, cardinal movements of labor, extension, descent, external rotation, internal rotation, flexion and expulsion. ${ }^{12}$ Recent reports suggest that intrapartum ultrasound imaging may be of assistance in overcoming these problems by facilitating application of a series of evaluations for determination of fetal head position and progression during labor. ${ }^{1-6}$ This would offer a better prediction of successful vaginal delivery. 
INTRAPARTUM SONOGRAPHY IN ASSESSMENT OF FETAL HEAD POSITION

Assessment of cervical dilatation, head position and descent of the head is important in labor monitoring. Use of intrapartum sonographic assessment of fetal head position was studied back in 1989 by Rayburn et al. ${ }^{13}$ in 86 women with labor with arrested cervical dilatation at $7 \mathrm{~cm}$ or more. Ultrasonographic technique was shown to improve the diagnosis of fetal head position, and was quite accurate in differentiating between posterior and anterior occipital positions. Since then, the use of intrapartum ultrasonography in the detection of fetal head position has been proven to be more precise than any other clinical transvaginal examination. For example, in one study use of intrapartum ultrasonography determined that in most cases, persistent occipitoposterior position resulted from an intrapartum malrotation. ${ }^{14}$ Only $32 \%$ of persistent occipitoposterior positioned fetuses showed an absence of rotation from an initial occipitoposterior position recognized at the beginning of labor. Lieberman et al. ${ }^{15}$ carried out a prospective cohort study of 1562 women to assess alterations in fetal head position during labor. Sequential ultrasound examinations were performed on enrolment, epidural administration and throughout advanced labor $(>8 \mathrm{~cm})$. It was noted that only $20.7 \%$ of fetuses that were occipitoposterior in advanced labor remained occipitoposterior at delivery. Alterations in fetal head position were frequent and $36 \%$ of women had an occipitoposteriorally placed fetus on at least one ultrasound examination. Souka et al. ${ }^{16}$ evaluated the practicability of intrapartum transabdominal ultrasound imaging in determining fetal head position in contrast with transvaginal digitally examination in a longitudinal study of women in the first and second stages of normal or obstructed labor. The results of this study suggested that assessment of the fetal head position was not possible by digital assessment in $60.7 \%(122 / 201)$ of cases in the first stage and $30.8 \%(41 / 133)$ on the second stage of labor. When digital assessment was accessible, the connection with ultrasound assessment was average in the first stage of labor and good in the second stage. Overall, fetal head position as- sessment by digital examination was accurate in $31.3 \%$ of cases in the first stage and $65.7 \%$ in the second stage. ${ }^{16}$ The authors concluded that intrapartum ultrasound assessment was more accurate than digital examination in assessment of the fetal head position, especially in cases of obstructed labor, which often require medical intervention. It has also been reported that intrapartum ultrasonography increases the accuracy of assessment of fetal head position in active labor. ${ }^{7}$ Examination of 102 patients during active labor showed an overall rate of error $(76 \%)$ in the clinical determination of fetal head position, whereas intrapartum ultrasound increased the accuracy of fetal head position determination during the second stage of labor. It was reported that the accuracy of intrapartum ultrasonography was $92 \%$ in the prediction of fetal head positions during spontaneous vaginal delivery. ${ }^{7}$ Adaptation to accommodate different parts of the fetal head to various segments of the pelvis is therefore a significant requirement for vaginal delivery. Such positional changes constitute the cardinal movements of labor, and include engagement, descent, flexion, internal rotation, extension, external rotation and expulsion.

\section{ENGAGEMENT OF FETAL HEAD}

Various sonographic modalities using trans-abdominal or trans-labial ultrasonography (USG) have been employed in the intrapartum determination of fetal head engagement. An imaginary line representing the pelvic inlet is demarcated by directing the transverse suprapubically positioned transabdominal transducer towards the maternal sacral promontory. Engagement of the fetal head (or the lack thereof) is ascertained according to whether or not the fetal biparietal diameter (BPD; the maximum transverse diameter of the fetal head) is depicted below or above the pelvic inlet, respectively. ${ }^{17}$ Fetal head engagement in the maternal pelvis pertains to BPD having successfully traversed the anteroposterior diameter of the pelvic inlet. ${ }^{8}$

\section{FETAL HEAD FLEXION AND DESCENT}

Both flexion and descent of the fetal head contribute to successful engagement, which may occur 
during the last weeks of pregnancy or, as suggested from recent evidence among nulliparous patients, ${ }^{18}$ only after labor commences. Ultrasound imaging may be utilized with relative ease to depict flexion of the fetal head, as may be noted directly while tracking the fetal spine in a sagittal plane towards the fetal head. ${ }^{19,20}$ Of note, various degrees of deflexion or extension of the fetal head at the initiation of labor have been associated with lack of engagement. This may reflect various mechanical problems, such as obstruction of the lower uterine segment or the occurrence of face presentation (acute hyperextension), which may prevent successful engagement. Varying degrees of deflection of the fetal head may be noted as a result of movement of the depicted BPD from an imaginary line parallel to the pelvic inlet, to any angle up to 90 , the latter representing an acutely hyperextended fetal head-face presentation. ${ }^{20}$

\section{INTRAPARTUM ULTRASONOGRAPHY IN DETECTION OF MATERNAL SYMPHYSIS}

Intrapartum ultrasound examination has been efficiently used for the assessment of the breadth of the maternal symphysis pubis upon engagement of the fetal head and once the major diameter of the fetal head was at the stage of the ischial spines. ${ }^{21}$ Average width of the symphysis pubis at the onset of labor was calculated to be $5.8 \mathrm{~mm}$. In patients with pelvic pain, average separation of the symphysis pubis during labor was reported to be $0.2 \mathrm{~mm}$ during pregnancy. From intrapartum ultrasound, it could be concluded that symphyseal separation during labor is minimal regardless of parity or eventual birth weight.

\section{UTERINE CONTRACTIONS}

An assessment of utility of trans-vaginal sonography of the cervix before, during or after a uterine contraction in the first stage of labor in prognosis of labor path was performed by Saito et al. ${ }^{22}$ They analyzed the degree of cervical shortening during a contraction compared to cervical length before the contraction in 39 nulliparous and 34 parous women with uncomplicated singleton, term pregnancies in the first stage of labor. The results of the study indi- cated that through a uterine contraction during the normal course of labor, the cervix was shortened by approximately $50 \%$ on average. The extent of cervical shortening was notably higher in the normal latent and active phases than in the protracted active phase, prolonged latent phase and in false labor. Nulliparous and parous women showed about the same degree of shortening in the latent and active phases. This study suggests that real-time intrapartum ultrasound examination in early labor might help in discrimination between inept and normal uterine contractions. ${ }^{22}$ Other studies, meanwhile, suggest the applicability of this technique in assessment of third stage of labor.

\section{EXAMINATION OF THIRD STAGE LABOR WITH INTRAPARTUM ULTRASOUND}

Ultrasound imaging has enabled further understanding of the physiology of the third stage of labor. ${ }^{8}$ In 1993 Herman et al. evaluated 25 normal deliveries compared to five with a prolonged third stage of labor. ${ }^{23}$ Normal third-stage labor could be split into four phases: the latent form, qualified by a thick, placenta-free wall and thin, placenta-site wall; the contraction stage, with a thickening of the placenta site wall (from $<1 \mathrm{~cm}$ to $>2 \mathrm{~cm}$ ); the withdrawal phase, when the placenta completes its separation and detaches; and the expulsion phase, which involves a sliding motion of the placenta. ${ }^{23}$ Routinely used uterotonic agents had surprisingly little impact on the findings. In another study aimed at characterization of normal and abnormal third stage placental separation, gray scale and color Doppler sonography was used to define the three sonographic phases of separation, namely the interval between delivery of the fetus and the beginning of placental separation (latent phase), monophasic or multiphasic shearing off of the placenta (detachment phase), and the interval between completing placental separation and vaginal delivery of the placenta (expulsion phase). ${ }^{24}$ In 57 cases in which placental separation was clinically normal, inter-placenta/myometrium blood flow was observed to stop immediately after fetal delivery during the latent period. The authors concluded that this cessation of blood flow following 
fetus delivery was the sonographic hallmark of normal placental separation, whereas persistent blood flow as demonstrated by color Doppler sonography was suggestive of placenta accreta. ${ }^{24}$ Application of intrapartum ultrasound examination in clinical management of the third stage of labor has centered mainly upon retained placenta or placental fragments and confirmation of placenta accreta. ${ }^{8}$ However, there is evidence to suggest that this could be extending application of the technique to evaluation of fetal head progression.

\section{INTRAPARTUM ULTRASOUND IN} EVALUATING THE PROGRESSION OF THE FETAL HEAD

A number of reports have provided intrapartum sonographic data about the progression of the fetal head in an infra-pubic approach, aligned in the midsagittal plane, with machine contexts adjusted for widest insonation angle, maximum depth and lowest output frequency. This would allow the pubic symphysis and fetal skull contour to be visualized almost completely along the screen. The patient in a semirecumbent position with her legs flexed may be tempted to push (push test); in this context, USG could be employed to dynamically determine the advance of the fetal head within the birth canal. ${ }^{7}$ In 2009, Barbera et $\mathrm{al}^{20}$ carried out a study to measure fetal head station and descent during labor using transperineal ultrasound (TPU) imaging in 88 term patients with a singleton fetus in cephalic presentation. This study identified angle of fetal head descent as measured by TPU as an objective, accurate and reproducible means of fetal head descent assessment during labor. The same technique was used by Kalache et al., ${ }^{25}$ in 2009 on 26 term women with prolonged second stage of labor and occipitoanterior position. This study disclosed a substantial kinship between the angle of progression and the indication of cesarean section delivery. The authors established that the calculated probability of either an easy and successful vacuum extraction or spontaneous vaginal delivery for an angle of progression of $120^{\circ}$ was $90 \%$. The Intrapartum ultrasonographic technique is quite effective in a prospective analysis of the angle of progression, ${ }^{25}$ linear measurements and the semi-subjective assessment of head direction during the normal phase of labor. ${ }^{26}$ These studies suggest that intrapartum ultrasound has the potential to become an important part of assessment of fetal head position, and for the decision-making before instrumental vaginal delivery. Both supervision of the labor progress and performing the safe operative delivery can be effectively monitored with the help of ultrasound. In addition, it can also be used for effective prediction of whether a vaginal delivery would be successful. ${ }^{7}$

\section{THREE DIMENSIONAL ULTRASOUND}

Recently, three-dimensional assessment software designed for labor measurements was developed and all the measurements noted above may be computed based on a single 3D volume scan, stored, superimposed and displayed with previous set of measurements in order to facilitate visualization of any significant alterations in fetal head progression and rotation during labor. ${ }^{27}$ The three measurements, head direction, angle of progression and progression distance, together with the angle from the center crease to the vertical line of the pelvis have been integrated into 3D software called Sonography-based Volume Computer Aided Display, (SonoVCAD). The aim of SonoVCAD is to supply an objective measure of advance of the fetal brain during labor. However, there are currently no prospective studies using this instrument to establish which of the measurements are more reliable and accurate in the anticipation of vaginal delivery and in general there is a restriction of these measurements to an anterior position of the fetal occiput. ${ }^{27}$

\section{CONCLUSION}

Worldwide, reduction in cesarean delivery rates is a clinical priority. However, while vaginal birth is a natural process, it occasionally calls for urgent medical intervention to ward off damage to the laboring woman and her unborn child. Thus effective and readily applicable methods for monitoring vaginal delivery and offering timely indication of potential problems are a priority. Intrapartum ultrasound imaging has the potential to fill this gap. 
To date, its application in clinical management of the third stage of labor has mainly focused on retained placenta or placental fragments and confirmation of placenta accrete. However, evidence shows that intrapartum trans-labial ultrasound is a simple yet effective technique that improves the understanding of normal and abnormal labor. It contributes to more effective evaluation and monitoring of the birth progress and offers a more scientific foundation for assessment of labor. Furthermore, developing the usage of ultrasound is of essential importance in facilitation of safe operative delivery and can aid in the prediction of whether a vaginal delivery would be successful.

\section{REFERENCES}

1. Tutschek B, Braun T, Chantraine F, Henrich $W$. A study of progress of labour using intrapartum translabial ultrasound, assessing head station, direction, and angle of descent. BJOG 2011;118(1):62-9.

2. Khalil O, Elbadawi $E$, Abdelnaby M, Zayed L $\mathrm{H}$. Assessment of the progress of labor by the use of intrapartum ultrasound. Alex J Med 2012;48(4):295-301.

3. Dückelmann AM, Bamberg C, Michaelis SA, Lange J, Nonnenmacher A, Dudenhausen JW, et al. Measurement of fetal head descent using the 'angle of progression'on transperineal ultrasound imaging is reliable regardless of fetal head station or ultrasound expertise. Ultrasound Obstet Gynecol 2010;35(2):21622.

4. Akmal S, Tsoi E, Nicolaides KH. Intrapartum sonography to determine fetal occipital position: interobserver agreement. Ultrasound Obstet Gynecol 2004;24(4):421-4.

5. Henrich W, Dudenhausen J, Fuchs I, Kämena A, Tutschek B. Intrapartum translabial ultrasound (ITU): sonographic landmarks and correlation with successful vacuum extraction. Ultrasound Obstet Gynecol 2006;28(6):75360.

6. Sherer DM. Can sonographic depiction of fetal head position prior to or at the onset of labor predict mode of delivery? Ultrasound Obstet Gynecol 2012;40(1):1-6.

7. Iliescu D, Antsaklis P, Paulescu D, Comanescu A, Tudorache $S$, Antsaklis $A$, et al. Applications of ultrasound in prelabor and labor. Donald School Journal of Ultrasound in Obstetrics and Gynecology (DSJUOG) 2012;6(3):257-69.

8. Sherer DM. Intrapartum ultrasound. Ultrasound Obstet Gynecol 2007;30(2):123-39.

9. Tongprasert F, Jinpala S, Srisupandit K, Tongsong $T$. The rapid biophysical profile early intrapartum fetal well-being assessment. Int $\mathrm{J}$ Gynaecol Obstet 2006;95(1):14-7.

10. Sherer DM, Schwartz BM, Mahon TR. Intrapartum ultrasonographic depiction of fetal malpositioning and mild parietal bone com- pression in association with uterine leiomyoma. J Matern Fetal Med 1999;8(1):2831.

11. Szunyogh N, Galo S, Zubor P, Visnovsky J. Atypical ductus venosus blood flow pattern during a prolonged fetal heart rate deceleration in labor. Ultrasound Obstet Gynecol 2006;27(6):712-5.

12. Lucas MJ, Sharma SK, McIntire DD, Wiley J, Sidawi JE, Ramin SM, et al. A randomized trial of labor analgesia in women with pregnancyinduced hypertension. Am J Obstet Gynecol 2001;185(4):970-5.

13. Rayburn WF, Siemers KH, Legino LJ, Nabity MR, Anderson JC, Patil KD. Dystocia in late labor: determining fetal position by clinical and ultrasonic techniques. Am J Perinatol 1989; 6(3):316-9.

14. Gardberg M, Laakkonen E, Sälevaara M. Intrapartum sonography and persistent occiput posterior position: a study of 408 deliveries. Obstet Gynecol 1998;91(5 Pt 1):746-9.

15. Lieberman E, Davidson K, Lee-Parritz A, Shearer $\mathrm{E}$. Changes in fetal position during labor and their association with epidural analgesia. Obstet Gynecol 2005;105(5 Pt 1):97482.

16. Souka AP, Haritos T, Basayiannis K, Noikokyri $\mathrm{N}$, Antsaklis A. Intrapartum ultrasound for the examination of the fetal head position in normal and obstructed labor. J Matern Fetal Neonatal Med 2003;13(1):59-63.

17. Dietz HP, Lanzarone V. Measuring engagement of the fetal head: validity and reproducibility of a new ultrasound technique. Ultrasound Obstet Gynecol 2005;25(2):165-8.

18. Ghi T, Maroni E, Youssef A, Morselli-Labate AM, Paccapelo A, Montaguti E, et al. Sonographic pattern of fetal head descent: relationship with duration of active second stage of labor and occiput position at delivery. UItrasound Obstet Gynecol 2014;44(1):82-9

19. Murphy K, Shah L, Cohen WR. Labor and delivery in nulliparous women who present with an unengaged fetal head. J Perinatol 1998; 18(2):122-5.
20. Barbera AF, Pombar X, Perugino G, Lezotte $D C$, Hobbins JC. A new method to assess fetal head decent in labor with transperineal ultrasound. Ultrasound Obstet Gynecol 2009; 33(3):313-9.

21. Björklund K, Lindgren PG, Bergström S, Ulmsten U. Sonographic assessment of symphseal joint distention intrapartum. Acta Obstet Gynecol Scand 1997;76(3):227-32.

22. Saito M, Kozuma S, Kikuchi A, Sakai M, Fujii $\mathrm{T}$, Unno N, et al. Sonographic assessment of the cervix before, during and after a uterine contraction is effective in predicting the course of labor. Ultrasound Obstet Gynecol 2003; 22(6):604-8.

23. Herman A, Weinraub Z, Bukovsky I, Arieli S, Zabow P, Caspi E, et al. Dynamic ultrasonographic imaging of the third stage of labor: new perspectives into third-stage mechanisms. Am J Obstet Gynecol 1993;168(5): 1496-9.

24. Krapp M, Baschat AA, Hankeln M, Gembruch U. Gray scale and color Doppler sonography in the third stage of labor for early detection of failed placental separation. Ultrasound Obstet Gynecol 2000;15(2):138-42.

25. Kalache KD, Dückelmann AM, Michaelis SA, Lange J, Cichon G, Dudenhausen JW. Transperineal ultrasound imaging in prolonged second stage of labor with occipitoanterior presenting fetuses: how well does the 'angle of progression' predict the mode of delivery? Ultrasound Obstet Gynecol 2009;33(3): 326-30.

26. Eggebø TM, Heien C, Økland I, Gjessing LK, Romundstad P, Salvesen KA. Ultrasound assessment of fetal head-perineum distance before induction of labor. Ultrasound Obstet Gynecol 2008;32(2):199-204.

27. Zimerman AL, Smolin A, Maymon R, Weinraub Z, Herman A, Tobvin Y. Intrapartum measurement of cervical dilatation using translabial 3-dimensional ultrasonography correlation with digital examination and interobserver and intraobserver agreement assessment. J Ultrasound Med 2009;28(10): 1289-96. 